\title{
Peran Relawan TIK Dalam Program Desa Broadband Terpadu Cikadu, Cianjur, Jawa Barat
}

\author{
Puji Hariyanti \\ Dosen Program Studi Ilmu Komunikasi, FPSB, Universitas Islam Indonesia \\ Jl. Kaliurang KM.14 Sleman Yogyakarta \\ puji.hariyanti@uii.ac.id
}

\begin{abstract}
ABSTRAK
Penelitian ini mengaji peranan Relawan Teknologi Informasi Komunikasi dalam menyukseskan program Desa Broadband Terpadu (DBT) Kementrian Komunikasi dan Informasi. Relawan TIK bertugas membantu pemerintah untuk menyosialisasikan program penggunaan akses informasi (internet), sekaligus pemberdayaan masyarakat melalui informasi, edukasi sosial, teknologi, dan komunikasi. Penelitian ini dilakukan dengan menggunakan metode deskriptif kualitatif, dengan pengambilan data melalui wawancara dan observasi langsung dengan informan Relawan TIK dari Desa Cikadu, Kecamatan Cikadu, Kabupaten Cianjur, Jawa Barat dan observasi website desa cikadu.desa.id. Hasil penelitian menunjukkan bahwa Relawan TIK di Desa Cikadu memegang peranan yang sangat penting sebagai inisiator website desa, fasilitator antara pemerintah pusat dan pemerintah desa, pembuat isi website, mengelola website desa.
\end{abstract}

Kata kunci: Program Desa Broadband Terpadu, Kemkominfo, Relawan TIK, , website desa Cikadu Cianjur Jawa barat

\begin{abstract}
This study examines the role of Communication Information Technology Volunteers in succeeding of the Integrated Broadband Village (DBT) program of the Ministry of Communication and Information. ICT volunteers are in charge of helping the government to disseminate the use of information access (internet) program, as well as community empowerment through information, social education, technology, and communication. This research was conducted by using qualitative descriptive method, by taking data through interview and direct observation with Informant ICT Volunteers from Cikadu Village, Cikadu Sub-district, Cianjur Regency, West Java and observation of cikadu.desa.id village website. The results show that ICT Volunteers in Cikadu Village play a very important role as village website initiator, facilitator between central government and village government, website content maker, village website management.
\end{abstract}

Keywords: Integrated Broadband Village, Communication Information Technology Volunteers, village website 


\section{Pendahuluan}

Sebagian besar penduduk Indonesia tinggal di perdesaaan, tapi pembangunan perdesaan selama ini masih menemui banyak kendala. Desa dan masyarakatnya masih berada pada kondisi serba kekurangan dan tertinggal dibanding kondisi masyarakat kota, khususnya dalam bidang sosial ekonomi (Suharto, 2016: 2). Ada anggapan bahwa pembangunan nasional justru menciptakan kesenjangan antara desa dan kota. Kondisi ini menciptakan ketidakadilan, kemiskinan, dan keterbelakangan di kawasan perdesaan.

\section{Data Dirjen PUM Kementrian} Dalam Negri (Desember 2014) menyebutkan jumlah desa di Indonesia sebanyak 74.045, sedangkan data potensi desa 2011 yang diolah Kementrian Desa, PDT, Transmigrasi (2014) menunjukkan desa tertinggal sebanyak 39.091 (52,79\%), dan desa sangat tertinggal 17.268 (23,32\%). Jumlah desa sangat tertinggal terbanyak berada di Pulau Papua, disusul Sumatera, Kalimantan, Sulawesi, Maluku, Nusa Tenggara, dan Bali (kominfo.go.id).

Kebijakan pemerintah dalam mengurangi kesenjangan wilayah desa dan kota antara lain dengan menerbitkan UU Desa untuk pembangunan desa, pemberdayaan masyarakat desa, dan pengembangan kawasan perdesaan. UU No.6 tahun 2014 tentang Desa menjadi prioritas penting bagi Pemerintah Joko Widodo. Desa akan diberdayakan menjadi “kekuatan besar' yang akan memberikan kontribusi terhadap misi Indonesia yang berdaulat, sejahtera dan bermartabat. Joko Widodo merumuskan Sasaran Strategis Pembangunan Nasional, yaitu Sembilan Agenda Strategis Prioritas (NAWACITA). Untuk mengawal UU Desa, tertuang dalam Nawacita ketiga, "membangun Indonesia dari pinggiran dengan memperkuat daerah-daerah dan desa dalam kerangka Negara kesatuan." Rencana Pembangunan Jangka Menengah Nasional 2015 sampai dengan 2019 telah mengamanatkan sasaran pembangunan desa untuk mengurangi jumlah desa tertinggal hingga 5.000 desa, dan meningkatkan jumlah desa mandiri sedikitnya 2.000 desa. (kominfo.go.id). Ini juga didukung dalam susunan anggaran pendapatan belanja Negara untuk 2016 yang menitikberatkan pembangunan di daerah dan di perdesaan. Data Direktorat Penyusunan APBN, Kementerian Keuangan dalam Infografis GPR Kominfo (2015) menunjukkan APBN 2016 mendorong pembangunan daerah dan desa, dengan kenaikan jumlah dana transfer daerah dan dana desa tahun ini naik $16 \%$ dari tahun sebelumnya (Hariyanti \& Tanjung, 2017: 688).

Program Pembangunan Desa Broadband Terpadu (DBT) merupakan program yang dicanangkan pemerintah dalam rangka pengembangan potensi desa 
melalui pemanfaatan teknologi informasi dan komunikasi. Program ini dilaksanakan oleh Kementerian Komunikasi Informasi (Kemkominfo). Program DBT diperuntukkan bagi desa nelayan, desa pertanian, dan desa pedalaman untuk mendukung dan membantu kegiatan masyarakat setempat sehari-hari. Desadesa yang menjadi sasaran program DBT disebut Desa Broadband Terpadu, yaitu desa $3 \mathrm{~T}$ (tertinggal, terdepan, terluar) yang akan dilengkapi dengan fasilitas jaringan atau internet, perangkat akhir pengguna dan aplikasi yang sesuai dengan karakteristik penduduk setempat.

Program DBT menjadi bagian dari program percepatan penetrasi internet yang digalakkan pemerintah. Ini karena Indonesia merupakan salah satu negara yang ikut menandatangani deklarasi "Word Summit on Information Society" (WSIS) pada 2003. Dalam deklarasi WSIS, disebutkan bahwa hingga 2015, sebanyak 50 persen penduduk dunia harus memiliki akses terhadap informasi (akses internet).

Pemerintah membagi tiga tahapan dalam pencapaian program percepatan penetrasi internet di Indonesia. Tahap pertama, 2011-2012. Langkah awal menuju "Indonesia Conneted". Kedua, 2013-2014. Terwujudnya masyarakat Indonesia yang informatif dan sadar terhadap akses internet. Ketiga, 2015-2019. Masyarakat Indonesia ditargetkan sudah sangat intensif dalam penggunaan internet (kominfo.go.id).
Salah satu desa yang menjadi Desa Broadband Terpadu adalah Desa Cikadu, Kecamatan Cikadu, Kabupaten Cianjur, Jawa Barat. Seperti tertulis dalam website Desa Cikadu (cikadu.desa.id), pada 20 Desember 2016, Kemkominfo melalui Balai Penyedia dan Pengelola Pembiayaan Telekomunikasi dan Informatika (BP3TI) memberikan akses internet yang dirasakan manfaatnya oleh Pemerintahan Desa Cikadu dan masyarakat sekitarnya. Selain itu, Pemerintah Desa Cikadu juga menerima Sistem Informasi Desa berbasis daring (website cikadu.desa.id) dan luring (App SIDeKa) dengan nama aplikasi Sistem Informasi Desa dan Kawasan (SIDeKa) yang telah dikelola oleh Pemerintah Desa Cikadu. Dengan SIDeKa, pemerintah desa bisa mempromosikan potensi dan produk desanya, menginformasikan kondisi desanya, mengupdate data kependudukan dan transparansi Anggaran Pendapatan dan Belanja Desa (APBDes) secara terbuka kepada masyarakat, serta bentuk laporan kepada pemerintah.

Sebelumnya, pada 2014, Desa Cikadu juga mendapatkan penghargaan "Inisiatif dan Kreativitas dalam Pemanfaatan TIK dan Penggunaan Domain “Desa.ID” pada Festival Destika. Festival Destika diselenggarakan oleh Kemkominfo bersama Gerakan Desa Membangun, Badan Prakarsa Pemberdayaan Desa dan Kawasan, Relawan TIK, Gedhe Foundation, PANDI mengapresiasi partisipasi komunitas desa 
pengguna domain desa.id. Relawan TIK dan GDM Cianjur A. Nuroni menceritakan bahwa kondisi akses internet di Desa Cikadu sangat terbatas sehingga untuk mengunggah informasi dilakukan saat ada pemuda desa ke kota. Website desa masih dikelola Relawan TIK bukan perangkat desa karena keterbatasan kemampuan penguasaan teknologi informasi (cikadu.desa.id).

Kementerian Komunikasi dan Informatika (Kemkominfo) membentuk relawan teknologi informasi komunikasi (TIK) di seluruh provinsi untuk mendukung program percepatan penetrasi internet masyarakat. Pembentukan relawan TIK dimulai 2011. Relawan TIK bertugas membantu pemerintah untuk menyosialisasikan program penggunaan akses informasi (internet), sekaligus pemberdayaan masyarakat melalui informasi, edukasi sosial, teknologi, dan komunikasi.

Artikel ini akan memaparkan peran relawan TIK di Desa Cikadu dalam pengelolaan website desa, yaitu cikadu.desa.id. Desa Cikadu dipilih karena webite desa Cikadu masih aktif sampai sekarang, dibandingkan penerima penghargaan Destika pada 2014 lainnya. Selain itu, karena Desa Cikadu menjadi salah satu Desa Broadband Terpadu pada 2016. Pada 2017, Desa Cikadu masuk dalam daftar 20 desa penerima program Desa Emas (Enterpreneur, Mandiri, Adil dan Sejahtera) dari pemerintah Provinsi Jawa Barat.

\section{Tabel 1. Daftar Penerima Destika Award 2014}

\begin{tabular}{|c|c|c|}
\hline No. & $\begin{array}{c}\text { Desa } \\
\end{array}$ & Keterangan \\
\hline 1. & Gampong Cot Baroh, Kab. Pidie, Aceh & Website dapat diakses \\
\hline 2. & Desa Cikadu, Kab. Cianjur, Jawa Barat & Website dapat diakses \\
\hline 3 . & Desa Bakbakan, Kab. Gianyar, Bali & $\begin{array}{l}\text { Website desa tidak ditemukan, } \\
\text { melainkan hanya blog }\end{array}$ \\
\hline 4. & $\begin{array}{l}\text { Desa Batumeranti, Kab. Tanahbumbu, } \\
\text { Kalimantan Selatan }\end{array}$ & Website tidak dapat diakses \\
\hline 5 . & $\begin{array}{l}\text { Desa Lakawali, Kab. Luwu Timur, Sulawesi } \\
\text { Selatan }\end{array}$ & $\begin{array}{l}\text { Website tidak dapat diakses, } \\
\text { melainkan facebook }\end{array}$ \\
\hline 6. & $\begin{array}{l}\text { Kampung Nurawi Miosindi, Kab. Yapen, } \\
\text { Papua }\end{array}$ & Website tidak dapat diakses \\
\hline 7. & Dishubkominfo Kab. Majalengka & Website tidak dapat diakses \\
\hline 8. & Dishubkominfo Kab. Tanahbumbu & Website tidak dapat diakses \\
\hline 9. & Dishubkominfo Provinsi Jawa Barat & Website tidak dapat diakses \\
\hline 10. & $\begin{array}{l}\text { Dishubkominfo Provinsi Kalimantan } \\
\text { Selatan }\end{array}$ & Website tidak dapat diakses \\
\hline
\end{tabular}

Sumber : Data peneliti hasil penelusuran online sampai Oktober 2017

Penelitian ini diharapkan menghasilkan gambaran atau model peran relawan TIK dalam pengelolaan internet dan aplikasi TIK, menemukan faktor- 
faktor pendukung dan penghambat program ini. Sehingga bisa menjadi acuan dalam pengelolaan website desa lainnya yang berada di Indonesia, mengingat banyak website desa di Indonesia yang sudah tidak aktif lagi.

\section{Metode Penelitian}

Penelitian ini menggunakan metode kualitatif yang berupaya mendeskripsikan data dan informasi mengenai peran Relawan TIK dalam menjalankan website desa Cikadu, Kecamatan Cikadu, Kabupaten Cianjur, Jawa Barat. Pengambilan data dilakukan dengan teknik triangulasi yang merupakan teknik pengumpulan data yang bersifat menggabungkan berbagai teknik pengumpulan data dan sumber data yang telah ada, sekaligus untuk menguji kredibilitas data (Sugiyono, 2010: 241).

Peneliti melakukan wawancara secara langsung dengan informan yang memiliki kapasitas terkait dengan website Desa Cikadu. Peneliti juga melakukan observasi langsung ke lapangan dengan mendatangi Desa Cikadu, Kecamatan Cikadu, Kabupaten Cianjur, Jawa Barat..

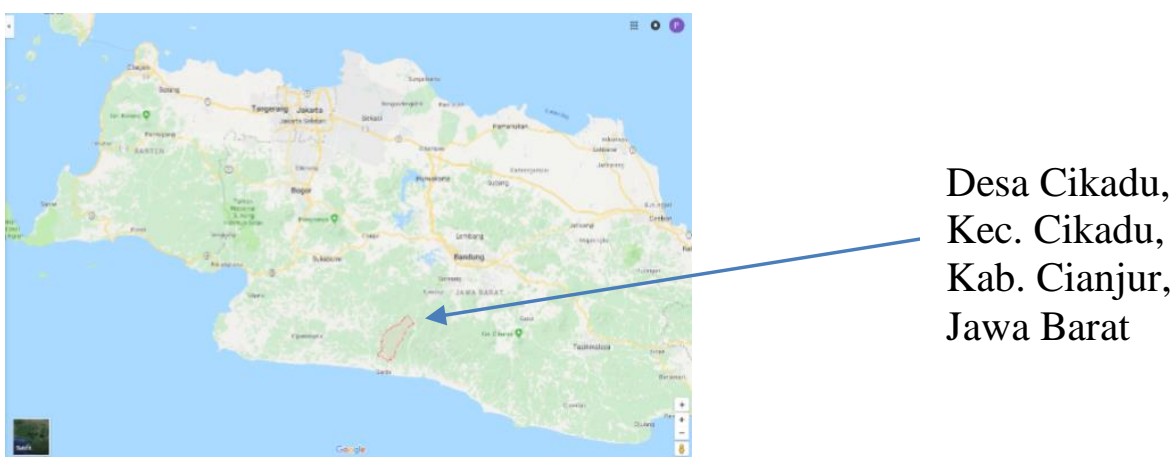

Gambar 1. Peta Desa Cikadu

Proses penelitian meliputi beberapa tahapan yang dimulai dari observasi dan wawancara kepada empat orang, yakni sebagai berikut.

1. A. Nuroni sebagai Relawan TIK sekaligus inisiator website Desa Cikadu sekaligus pengelola website desa sejak 2013 - sekarang. A. Nuroni juga tergabung dalam Gerakan Desa Membangun yang aktif dalam mengangkat isu pembangunan desa, pemberdayaan masyarakat desa, pelatihan TIK untuk desa, mendorong desa bersuara, informatif, aktif laporan ke umum atau pemerintahan.

2. Reza sebagai staff desa sekaligus pengelola website desa sejak 2016

3. Jaelani sebagai Kepala Desa Cikadu

4. Martono sebagai Ketua Badan Permusyawaratan Desa sekaligus perwakilan masyarakat

Pemilihan keempat informan tersebut mempertimbangkan peran penting mereka dalam pengelolaan dan pemanfaatan website Desa Cikadu. Selain 
itu peneliti melakukan observasi online pada isi website desa Cikadu di alamat cikadu.desa.id.

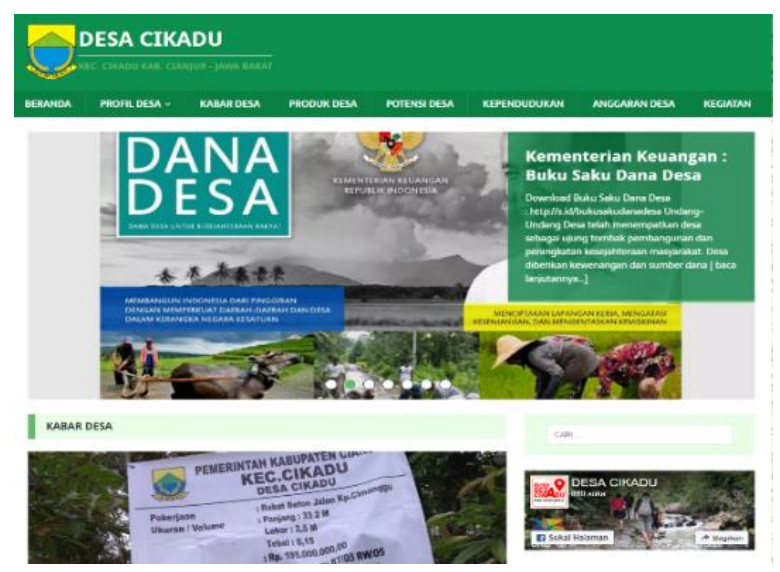

Gambar 2. Website Desa Cikadu.desa.id

\section{Temuan Penelitian}

Desa Cikadu merupakan desa dengan infrastruktur jalan yang masih sangat buruk, di mana jalan utama yang menjadi akses menuju desa masih berupa tanah berbatu. Jalan sepanjang Kecamatan Cikadu sangat parah. Cikadu menjadi kecamatan dengan akses jalan terburuk seKabupaten Cianjur. Desa Cikadu yang berada diperbukitan ini seolah-olah menjadi desa terisolasi kendati lokasinya tidak terlalu jauh dari ibu kota Kabupaten Cianjur (150 Km), tapi harus ditempuh selama 5 jam.

Buruknya kondisi jalan, diakui warga dan Kepala Desa Cikadu sangat berpengaruh pada perekonomian Desa Cikadu. Masyarakat harus mengeluarkan biaya yang lebih besar untuk menjual hasil bumi ke daerah Ciwidey atau ke Bandung. Desa Cikadu memiliki produk unggulan desa berupa gula aren dan sumber daya alam berupa pertanian, perkebunan, hutan lindung dan beberapa air terjun (Curug Cigugur, Curug Ngebul, dan Curug Cibeunteur) yang seharusnya bisa dijadikan kawasan wisata alam/ rekreasi jika akses jalan jalan mendukung. Potensi sumber daya alam bisa dimanfaatkan sebagai penggerak ekonomi masyarakat desa. Oleh karena itu, 53,89\% dari total APBD 2017 Desa Cikadu yang sebesar Rp.1.969.761.6oo dipergunakan untuk pembangunan fisik, terutama untuk perbaikan jalan utama yang biasa dilewati masyarakat untuk mengangkut hasil pertanian ke kota (cikadu.desa.id). 

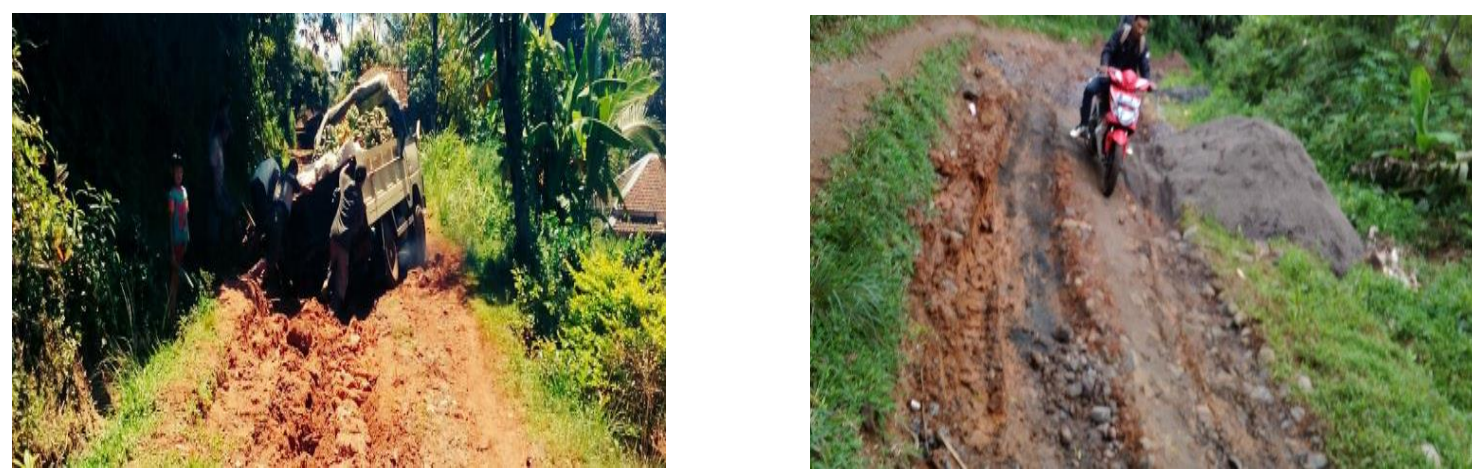

Gambar 3. Kondisi jalan Desa Cikadu

Sumber: www.kompasiana.com dan cikadu.desa.id

Desa Cikadu mulai mempunyai akses dengan dunia luar melalui website desa Cikadu.desa.id sejak 2014, dipelopori oleh seorang warga desa yang menjadi Relawan Teknologi Informasi Komunikasi (TIK), dan tergabung dalam jaringan penggiat pembangunan desa, yaitu Gerakan Desa Membangun (GDM). Desa ini dikunjungi pertama kali oleh pejabat, yaitu Wakil Gubernur jawa Barat, Deddy Mizwar, guna membahas perkembangan perekonomian dan pembangunan infrastruktur desa Cikadu (desamembangun.id).
Sebagai relawan TIK, A. Nuroni juga aktif menulis di portal berita daring terkait dengan perkembangan pembangunan infrastruktur jalan Cikadu Bandung. A. Nuroni menceritakan bahwa sejak 2013 sudah mulai aktif mengabarkan tentang Desa Cikadu. Keprihatinan atas ketertinggalan dari infrastruktur jalan, sekolah, air bersih, listrik, akses informasi dan komunikasi, dan tata kelola pemerintah desa memotivasinya untuk merintis website desa. (Nuroni, 2017)
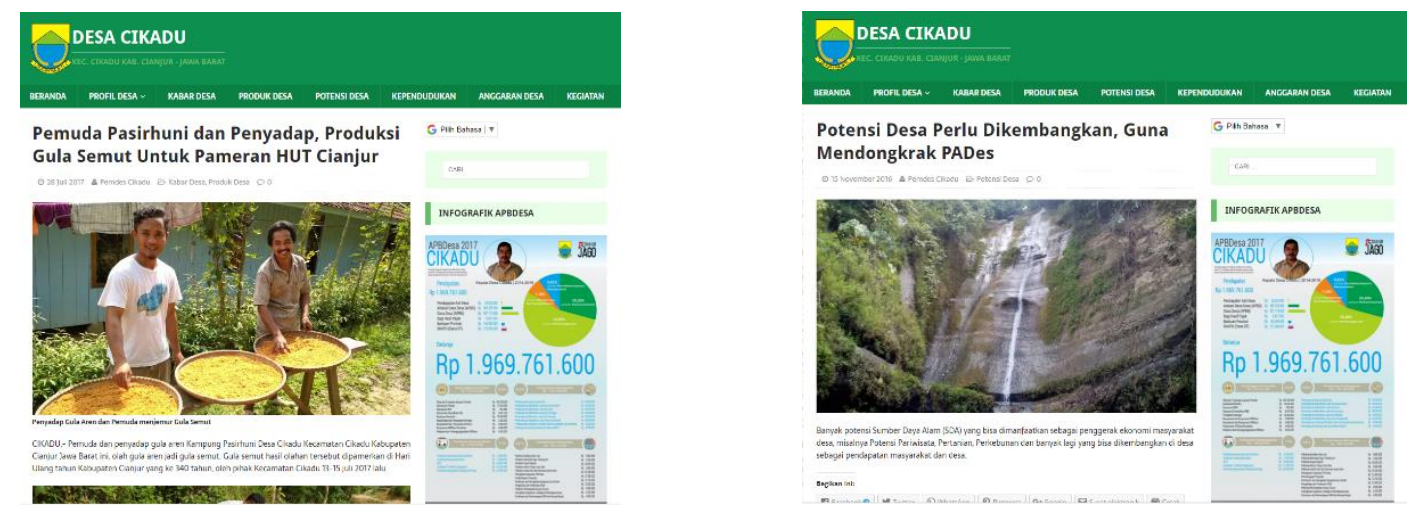

Gambar 4. Gula Semut, Produk unggulan dan Potensi Wisata Desa Cikadu

Sumber: cikadu.desa.id 
Keaktifan website Desa Cikadu dalam menginformasikan kondisi dan potensi yang dimiliki desa menjadikan Desa Cikadu salah satu penerima penghargaan Destika Award dalam acara Festival Desa Teknologi Informasi Komunikasi (DESTIKA) 2014. Festival DESTIKA diselenggarakan oleh Kemkominfo bertujuan untuk menggerakkan partisipasi komunitas desa melalui pemanfaatan TIK secara cerdas, kreatif, dan produktif. Selain itu, sebagai forum komunikasi dan ajang berkumpul serta berbagi pengalaman antarkomunitas dan penggiat desa, guna meningkatkan pemberdayaan desa di Indonesia. Festival DESTIKA menjadi wadah bagi desa-desa untuk mempromosikan potensi lokal sekaligus menggali ide serta bertukar informasi mengenai inovasi pemanfaatan TIK dari desa lainnya.

Geliat pembangunan di Desa Cikadu semakin terlihat ketika Pemerintah Desa Cikadu bersama Penggerak Gerakan Desa Membangun menggelar Lokakarya Desa dengan tema "Membangun Indonesia Dari Desa" dengan melibatkan unsur pemerintah desa, UMKM, akademisi, pemuda, masyarakat, serta mengundang berbagai elemen dari luar desa agar dapat bertukar informasi dan wawasan tentang pembangunan desa. Desa Cikadu masuk dalam daftar 20 desa penerima program Desa Emas (Enterpreneur, Mandiri, Adil dan Sejahtera) dari pemerintah Provinsi Jawa Barat. Penerima program ini nantinya akan mendapatkan program penguatan pembangunan dan pembinaan sesuai dengan potensi yang dimiliki desa. (cikadu.desa.id)

Kemajuan Desa Cikadu di bidang TIK, tidak bisa dilepaskan dari peran Relawan TIK yang sampai sekarang masih aktif mengawal pembangunan TIK di desa. Keberadaan relawan ini karena kapasitas sumber daya manusia baik perangkat desa maupun masyarakat desa Cikadu yang terbatas. Oleh karenanya, pengelolaan website masih sangat tergantung pada Relawan TIK, selain karena belum berhasilnya kaderisasi.

Nuroni, sebagai Relawan TIK bersama dengan Reza (staf desa), bertanggung jawab teknis pengelolaan website desa secara keseluruhan. Sebagai relawan TIK, Nuroni sejak 2013 hingga 2015 mengelola website desa. Masyarakat Desa Cikadu belum bisa memberikan kontribusi dalam pengelolaan website desa karena mereka tidak memahami manfaat dan penggunaan teknologi informasi. Berdasarkan data kependudukan hanya 2,4\% warga desa Cikadu yang berpendidikan SLTA, lainnya hanya tamat SD - SLTP dengan latar belakang pekerjaan sebagai petani dan wiraswasta.

Kepala Desa Cikadu juga menuturkan bahwa sebenarnya dibentuk tim pengelola website, dan untuk operasional sudah dianggarkan di anggaran tahunan desa. Namun, karena masyarakat masih lebih banyak yang 
belum memahami manfaat internet bagi masyarakat maupun perkembangan desa, partisipasi masyarakat dalam mengakses maupun berkontribusi mengirimkan konten website desa masih sangat minim (Jaelani, 2017).

Masyarakat Desa Cikadu masih sedikit yang memiliki komputer dan telepon pintar sehingga mereka belum banyak memanfaatkan internet. Masyarakat yang sudah memiliki "telepon pintar" baru digunakan untuk media sosial, belum untuk kegiatan lain yang lebih bermanfaat. Hambatan lainnya adalah belum banyak perangkat desa yang memiliki kesadaran tentang pentingnya dokumentasi pembenahan data desa. Pemahaman perangkat desa dianggap masih belum cukup memadai, demikian juga dengan penguasaan teknologi informasi jika dibandingkan dengan pegawai kota (Nuroni, 2017).
Kendala lainnya adalah infrastruktur. Ketersediaan wifi desa baru bisa dipenuhi sejak 2016 ketika Kemkominfo memberikan bantuan alat Metrasat. Selain itu, sambungan listrik juga menjadi kendala karena listrik di desa Cikadu sering mati dalam waktu yang cukup lama bisa sampai 3 jam (Reza, 2017).

Kurangnya pembinaan dari pemerintah dari tingkat kabupaten sampai provinsi juga dirasakan oleh relawan TIK Desa Cikadu. Bahkan sebagai desa terpencil, belum pernah menerima kunjungan dari pemerintah. Namun, setelah mempunyai website desa dan mulai mengunggah informasi-informasi terkait kondisi desa, pemerintah mulai memperhatikan melalui kunjungan Wakil Gubernur Jawa Barat, Kemkominfo melalui BP3TI dan BP2DK (Nuroni, 2017).

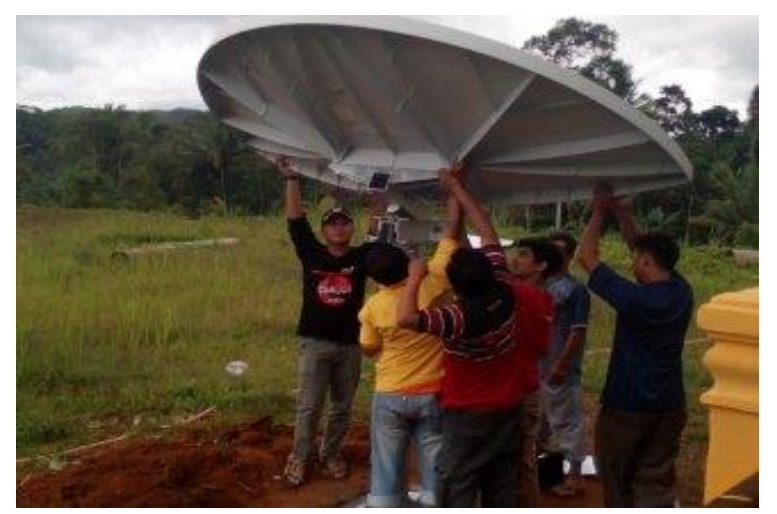

Gambar 5. Pemasangan Alat Metrasat Bantuan Kemkominfo sebagai Penyedia Jaringan Internet di Desa Cikadu (Sumber: Cikadu.desa.id) 


\section{Pembahasan}

Pembangunan, menurut Bjorn (dalam Dilla 2007: 59), adalah proses perubahan yang bersifat multidimensi menuju kondisi yang semakin mewujudkan hubungan yang serasi antara kebutuhan (needs) dan sumber daya (resources) melalui pengembangan kapasitas masyarakat untuk melakukan proses pembangunan. Dengan demikian, pada satu sisi, usaha-usaha pembangunan merupakan proses perubahan yang mempertimbangkan aspek kebutuhan, kepentingan, dan harapan-harapan masyarakat, sedangkan, pada sisi lain, pembangunan memperhitungkan ketersediaan dan kemampuan potensi sumberdaya yang mendukung. Ilustrasi Bjorn terlihat jelas pada gambar di bawah ini.

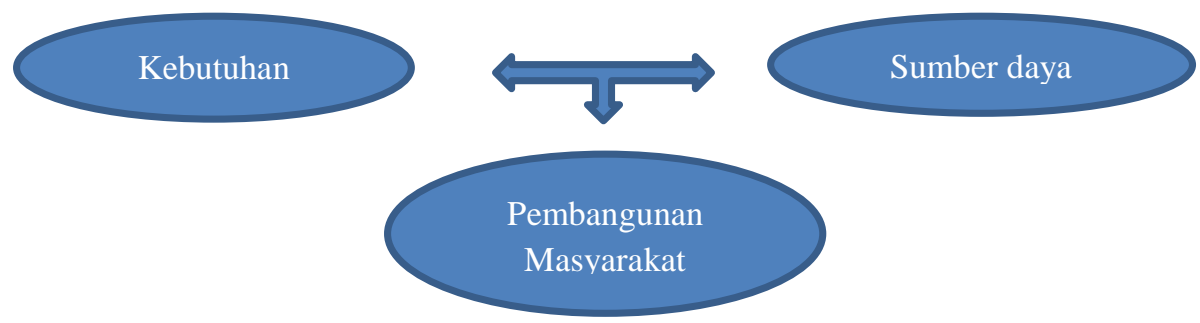

Sumber : Ilustrasi Hettne Bjorn (dalam Dilla, 2007: 59)

Dalam UU Nomor 6 Tahun 2014 tentang Desa (Bab I, pasal 1), antara lain disebutkan bahwa Desa adalah desa dan desa adat atau yang disebut dengan nama lain, selanjutnya disebut Desa, adalah kesatuan masyarakat hukum yang memiliki batas wilayah yang berwenang untuk mengatur dan mengurus urusan pemerintah, kepentingan masyarakat setempat berdasarkan prakarsa masyarakat, hak asal-usul, dan/atau hak tradisional yang diakui dan dihormati dalam system Negara kesatuan Republik Indonesia. Dijelaskan juga dalam UU Desa ini tersebut, pembangunan desa adalah upaya peningkatan kualitas hidup dan kehidupan untuk sebesar-besarnya kesejahteraan masyarakat desa.
Pemberdayaan masyarakat desa, di sisi lain, adalah upaya mengembangkan kemandirian dan kesejahteraan masyarakat dengan meningkatkan pengetahuan, sikap, ketrampilan, perilaku, kemampuan, kesadaran, serta memanfaatkan sumber daya melalui penetapan kebijakan, program, kegiatan, dan pendampingan yang sesuai dengan esensi masalah dan prioritas kebutuhan masyarakat Desa (www.dpr.go.id).

Berdasarkan UU tersebut, paradigma pembangunan pedesaan saat ini adalah pemberdayaan masyarakat desa. Menurut Usman (2015:176), paradigma pembangunan seperti ini adalah paradigma di mana masyarakat desa dibantu, didampingi dan difasilitasi untuk 
melakukan analisis dari masalah yang dihadapi, menemukan solusi, menggunakan sumber daya yang dimiliki, dan menciptakan aktivitas dengan kemampuannya sendiri.

Pemberdayaan masyarakat merupakan konsep pembangunan ekonomi yang merangkum nilai-nilai sosial dan mencerminkan paradigma baru pembangunan, yaitu berpusat pada masyarakat, partisipasi, pembinaan, dan berkelanjutan (Kartasasmita dalam Zulfida, 2015:310)

Strategi pemberdayaan (empowering) merupakan usaha melakukan perubahan dengan menempatkan masyarakat dan pemerintah atau swasta pada posisi yang sejajar. Masyarakat ditempatkan sebagai subyek pembangunan, dan terlibat aktif dalam proses formulasi dan eksekusi kebijakan dan program pembangunan (Usman, 2015: 5). Senada dengan itu, Robert Chambers (dalam Zulfida, 2015: 310) mengatakan bahwa masyarakat akan dapat menikmati pertumbuhan apabila diberdayakan. Awang (2010: 47) menambahkan bahwa keberdayaan masyarakat merupakan unsur dasar yang memungkinkan suatu masyarakat bertahan, mengembangkan diri, dan mencapai kemajuan.

Konsep pembangunan ini melibatkan peran serta masyarakat sipil, yang dapat beradaptasi dengan lingkungan sosial, budaya, ekonomi, dan politik atau dikenal dengan pembangunan yang berpusat pada rakyat (people centered development). Model ini merupakan alternatif baru untuk meningkatkan produktivitas dan distribusi pembangunan bagi masyarakat. Pembangunan pada paradigma ini didefinisikan sebagai strategi pemberdayaan masyarakat yang berorientasi pada nilai-nilai sosial budaya yang hidup dan berkembang. Artinya, proses proses pembangunan tidak saja menumbuhkan dan mengembangkan nilai tambah ekonomis, tetapi juga nilai tambah social secara adil (equity), setara (equality) dan partisipatif sebagai upaya pengembangan kapasitas manusia dan masyarakat berdasarkan pada spektrum memberdayakan masyarakat untuk memberdayakan diri mereka sendiri, mulai dari individu, kelompok, maupun masyarakat sehingga apapun bentuk pembangunan yang dilakukan harus melibatkan peran serta aktif masyarakat. Jadi, tujuan pembangunan pada paradigma ini adalah usaha meningkatkan kualitas hidup (kesejahteraan), yang berfokus pada pengembangan manusia (human development oriented) (Dilla, 2007: 105).

Dalam Lokakarya Desa Cikadu, dirumuskan tentang konsep pembangunan desa yang ideal. Konsep Gerakan Membangun Desa (top down) dan Gerakan Desa Membangun (bottom up). Hal ini sesuai dengan konsep yang ditawarkan Safi'I (2009:13), yaitu konsep pembangunan desa yang ideal adalah kombinasi antara pembangunan dengan ciri “dari atas ke bawah' (top down) dan 
pendekatan dari bawah ke atas (bottom up) bisa dijadikan pendekatan baru yang lebih komprehensif. Karena pembangunan desa yang hanya menggunakan satu pendekatan tidak akan bisa mensinergikan semua kepentingan, desa dan pemerintah.

Program Pembangunan Desa

Broadband Terpadu (DBT) juga menggunakan pendekatan kombinasi ini. Pemerintah melalui Kemkominfo menetapkan regulasi, memberikan fasilitas dan memberikan pelatihan agar penetrasi internet di masyarakat desa meningkat. Selanjutnya, pemerintah desa dan masyarakat diminta aktif berpartisipasi dalam pemanfaatan dan pengelolaan program ini. Tanpa adanya partisipasi dari masyarakat, program ini tidak akan bisa mencapai target sasarannya karena Program DBT bukan hanya pembangunan fisik tetapi juga pembangunan kapasitas sumber daya manusia di desa agar memiliki kemampuan untuk meningkatkan kemampuan secara individu maupun komunitas secara keseluruhan.

Sebagai Desa Broadband Terpadu, Cikadu mendapatkan fasilitas jaringan sehingga tidak lagi mengalami kesulitan dalam mengakses internet. Hanya saja, masyarakat Desa Cikadu masih minim kesadaran akan manfaat dan pemanfaatan teknologi ini sehingga sebagian besar masyarakat masih belum memanfaatkan teknologi yang sudah disediakan pemerintah. Padahal, program ini diadakan dalam rangka meningkatkan tingkat penetrasi internet masyarakat. Jika hanya sebagian masyarakat saja yang memanfaatkan, maka nampaknya perlu dievaluasi keberlanjutan program ini karena target yang belum tercapai.

Kehadiran

infrastruktur telekomunikasi dan informatika berpotensi mengakselerasi terjadinya perubahan sosial, ekonomi atau budaya masyarakat setempat, bilamana akses tersebut dimanfaatkan sesuai peruntukkannya. Oleh karena itu, setelah pembangunan infrastruktur telekomunikasi dan informatika di desa, diperlukan suatu pemantauan atau evaluasi terhadap pemanfaatan layanan dimaksud. Di sisi lain, masyarakat boleh jadi enggan memanfaatkan layanan karena tidak mengetahui bagaimana memanfaatkan layanan yang tersedia. Oleh karena itu, edukasi kepada masyarakat mengenai manfaat dan memanfaatkan internet diperlukan (Topohudoyo, 2011: 135).

Pendekatan infrastruktur sebagai fasilitas pendukung menempatkan posisi infrastruktur hanya sebagai salah satu saja di antara faktor-faktor yang menggerakkan perubahan dan optimalisasi implementasi kebijakan dan program pembangunan. Faktor lainnya kapasitas para pemangku kepentingan (stakeholders) baik personal, komunitas maupun sistem serta jejaring (network) dan logistik. Kapasitas personal merujuk pada ketrampilan dan pengetahuan subyek sasaran program pembangunan. Kapasitas komunitas 
merupakan kesediaan menjalin kerja sama, saling memberikan masukan, kesanggupan mengembangkan relasirelasi sosial yang saling menguntungkan. Kapasitas sistem tercermin pada pengembangan komunikasi, kerja sama, dan koordinasi di antara para pihak yang bertanggung jawab pada implementasi kebijakan dan program pembangunan. Yang dimaksud jejaring adalah relasi-relasi sosial yang dikembangkan oleh anggota masyarakat dengan pihak eksternal terutama dalam rangka memperoleh pelbagai informasi, menjalin interaksi dan melakukan transaksi yang terkait dengan pembangunan (Usman, 2015:11).

Selain infrastruktur, pembangunan akan sukses jika melibatkan berbagai pihak yang berkompeten dan berkepentingan (stakeholders). Oleh karena itu, dibutuhkan tenaga-tenaga terampil dan professional, baik perorangan maupun kelompok yang paham di bidangnya masing-masing.melalui tenaga-tenaga terdidik dan terampil, diharapkan dapat mempelopori, menggerakkan, membuka wawasan berpikir, ataupun menyebarluaskan proses perubahan tersebut. Para tenaga tersebut memiliki kualifikasi dan kemampuan sehingga disebut agen perubahan (agent of change). Para agen ini bisa saja berasal dari pemerintah maupun non pemerintah. Mereka terdiri dari birokrat, politisi, kelompok profesi, Lembaga Swadaya Masyarakat (LSM), organisasi masyarakat, dan lain-lain yang peduli terhadap pemberdayaan masyarakat di tingkat bawah. (Dilla, 2007:142)

Seorang agen yang berperan sebagai komunikator akan mampu melakukan perubahan, sikap, pendapat, dan tingkah laku sasarannya (komunikasi) jika memiliki kredibilitas dan daya tarik. Kredibilitas, menurut Rogers (dalam Dilla, 2007:143), adalah tingkat di mana komunikator dipersepsi sebagai suatu kepercayaan dan kemampuan oleh penerima. Kredibilitas komunikator akan mempengaruhi perubahan sikap penerima pesan, semakin tinggi kredibilitas komunikator maka tingkat kepercayaan komunikan semakin tinggi. Ini karena dalam proses penyampaian komunikasi, komunikan tidak hanya memperhatikan apa yang disampaikan komunikator, tetapi siapa yang menyampaikan pesan.

Pada tataran pragmatis, fungsi agen perubahan ini meliputi fungsi pemberi-penerus informasi dan penghubung serta penjelas. Seringkali, agen perubahan berasal dari dalam lingkungan masyarakat sehingga mempermudah persuasi dalam penerimaan ide pembangunan. Karena mereka diyakini mengetahui seluk beluk karakteristik masyarakat tersebut. Melalui agen atau penyuluh pembangunan, suatu ide, gagasan atau inovasi baru yang berguna dapat diperkenalkan dan dimanfaatkan sehingga fungsi komunikator pembangunan mengandung arti usaha pendidikan, persuasif, penyampaian ide-ide baru (inovasi) yang 
bertujuan meningkatkan pengetahuan, ketrampilan, wawasan, dan cita-cita menuju pada suatu perubahan sikap dan tingkah laku. Dalam kaitan ini, dapat disimpulkan bahwa agen perubahan atau komunikator pembangunan adalah orang atau kelompok yang terdiri dari tenaga terdidikl dan terampil untuk melakukan perubahan sosial melalui informasi pembangunan, secara terencana, sistematis, sinergi, dan terintegrasi (Dilla, 2007:145).

Dalam kasus Desa Cikadu, selain mendapatkan infrastruktur jaringan internet, pemerintah Desa Cikadu juga menerima Sistem Informasi Desa berbasis daring (website cikadu.desa.id) dan luring (App SIDeKa) dengan nama aplikasi Sistem Informasi Desa dan Kawasan (SIDeKa) yang telah dikelola oleh Pemerintah Desa Cikadu. Dengan SIDeKa, pemerintah desa bisa mempromosikan potensi dan produk desanya, menginformasikan kondisi desanya, mengupdate data kependudukan dan transparansi Anggaran Pendapatan dan Belanja Desa (APBDesa) secara terbuka kepada masyarakat, serta bentuk laporan kepada pemerintah. Namun dalam pengelolaan website desa di Desa Cikadu, kapasitas personal belum mendukung. Bahkan perangkat desa sekalipun baru mulai mengenai teknologi informasi. Peran motivator desa yang merangkap sebagai Relawan TIK sangat dominan sehingga keberlanjutan program DBT juga sangat tergantung pada Relawan TIK. Namun, karena keterbatasan jumlah Relawan TIK maka belum mampu menularkan pengetahuan dan penguasaan teknologi informasi dan komunikasi kepada masyarakat.

Kredibilitas Relawan TIK Desa Cikadu sebagai komunikator pembangunan tidak diragukan oleh masyarakat dan perangkat Desa. Ini karena beragam usaha yang dilakukan Relawan TIK Desa Cikadu telah membuahkan hasil. Desa Cikadu yang awalnya desa tertinggal kini sudah menjadi desa yang "melek internet." Walaupun pembangunan fisik masih terus berjalan, masyarakat dan perangkat desa Cikadu mengakui bahwa peran relawan TIK sangat besar membawa perubahan di desa mereka. Meskipun demikian, ada masalah yang dihadapi, yakni relawan TIK tidak selalu berada di desa untuk meng-update perkembangan informasi desa melalui website sehingga di beberapa desa lain, website desa tidak lagi aktif karena "ditinggalkan" oleh relawan TIK yang pindah ke daerah lain atau mendapat pekerjaan lain.

Hasil penelitian di Desa Cikadu serupa dengan observasi awal peneliti pada program website desa di Desa Batu Meranti, Kecamatan Sungai Loban, Kabupaten Tanah Bumbu, Kalimantan Selatan yang sama-sama menerima penghargaan Destika pada 2014. Website desa tersebut sekarang sudah tidak lagi bisa diakses karena motivator desa yang awalnya bertanggung jawab terhadap website desa memiliki pekerjaan lain, dan 
belum sempat melakukan kaderisasi. Selain itu, kapasitas perangkat desa yang belum memadai untuk mengelola website desa sehingga webisite desa tidak bisa diakses lagi.

Hasil penelitian ini sama dengan hasil penelitian BPPI (2010) dan Puslitbang Postel (2010) berkait dengan program desa pintar, dan pemanfaatan fasilitas USO yang menunjukkan bahwa program ini jauh dari keberhasilan artinya program USO tidak mempu mewujudkan tujuannya, yakni terhubungnya antara desa-desa di Indonesia. Penelitian ini juga menemukan bahwa perangkat desa dan masyarakat sekitar fasilitas internet belum memahami secara benar tujuan dan pemanfaatan program ini. Pemahaman tersebut masih sangat kurang sehingga berimbas pada pembiaran atau penggunaan fasilitas yang tidak sesuai dengan tujuan program (Darmanto: 136). Di sisi lain, fasilitas telekomunikasi kebanyakan ditempatkan di balai desa sehingga menimbulkan keenganan masyarakat untuk dating memanfaatkan fasilitas yang ada, sosialisasi juga masih sangat kurang dilakukan. Selain itu, fasilitas yang ada kebanyakan digunakan untuk kegiatan lain misalnya untuk mengetik laporan, surat menyurat, dan kegiatan desa lainnya.

Temuan ini sama persis dengan yang terjadi di Desa Cikadu. Di Desa Cikadu, selain karena tingkat pendidikan mayoritas masyarakat rendah, tapi kurangnya partisipasi mereka terhadap program Desa Broandband Terpadu juga sangat minim. Masyarakat belum memiliki kesadaran akan tujuan dan pemanfatan internet bagi kehidupan mereka seharihari sehingga website Desa Cikadu sejauh ini hanya dimanfaatkan oleh Relawan TIK dan perangkat desa untuk menginformasikan potensi yang dimiliki desa dan perkembangan pembangunan desa untuk transparansi penggunaan dana desa.

\section{Kesimpulan}

Pembangunan Desa Broadband Terpadu (DBT) di Desa Cikadu sudah berhasil menyediakan fasilitas internet bagi masyarakat desa. Namun, belum bisa meningkatkan kualitas masyarakat desa karena partisipasi masyarakat untuk aktif memanfaatkan program ini sangat minim. Peran relawan TIK di Desa Cikadu sangat penting karena sudah bisa menginisiasi dan mengelola website desa agar tetap berjalan. Namun, rendahnya tingkat partisipasi masyarakat terhadap program ini menunjukkan bahwa relawan TIK belum secara optimal menjalankan perannya sebagai pendamping masyarakat dalam pemanfaatan program ini.

$$
\text { Sesuai dengan strategi }
$$
pembangunan desa, yaitu pemberdayaan, maka masyarakat desa hendaknya dibantu, didampingi dan difasilitasi untuk melakukan analisis dari masalah yang dihadapi, menemukan solusi, menggunakan sumber daya yang dimiliki, dan menciptakan aktivitas dengan 
kemampuannya sendiri. Jika hanya sekedar penyediaan fasilitas, maka masih jauh dari tujuan pembangunan memberdayakan masyarakat

\section{DAFTAR PUSTAKA}

Awang, Azam. (2010). Implementasi Pemberdayaan Pemerintah Desa. Yogyakarta: Pustaka Pelajar.

Darmanto. (2011). "Faktor Keberhasilan dan Hambatan Penerapan Teknologi Informasi (TIK) dalam Penyelenggaraan Pemerintah di Kabupaten Sragen" dalam Bunga Rampai: Hasil Penelitian dan Pengkajian Teknologi Informasi dan Demokratisasi. Yogyakarta: BPPKI.

Dilla, Sumadi. (2007). Komunikasi Pembangunan: Pendekatan Terpadu. Bandung: Simbiosa Rekatama Media.

Hariyanti, Puji, Sumekar Tanjung. "Implementasi Pengelolaan Website Desa Pejeng di Gianyar Bali dalam Program Desa Broadband Terpadu." Prosiding Conference on Media, Communication, and Sociology. Yogyakarta: Universitas Atma Jaya.

Nugraha, Aat Ruchiat, Rosnandar Romli. Strategi Komunikasi Pembangunan pada Program "Desa Peradaban" sebagai Bentuk Peningkatan Citra Pemerintah Daerah. Jurnal Kajian Komunikasi. Vol. 1, No.1, Desember 2012. Bandung: LP3 Fikom Universitas Padjadjaran.
Safi'I, M. (2009). Perencanaan Pembangunan Daerah. Malang: Averroes Press.

Suharto, Didik G. (2016). Membangun Kemandirian Desa. Yogyakarta: Pustaka Pelajar

Topohudoyo. (2011). Optimalisasi Pemanfaatan Fasilitas Internet Desa Hasil Penetrasi Program OSU (Sebuah Penelitian Tindakan di Desa Sigeblog, Kecamatan Banjarmangu, Kabupaten Banjarnegara” dalam Bunga Rampai: Hasil Penelitian dan Pengkajian Teknologi Informasi dan Demokratisasi. Yogyakarta: BPPKI.

Usman, Sunyoto. (2015). Perubahan Sosial. Yogyakarta: Pustaka Pelajar

Zulfida, Ida, dkk. (2015). Kinerja Program Nasional Pemberdayaan Masyarakat Mandiri Perdesaan di Kabupaten Bandung .MIMBAR. Jurnal Sosial dan Pembangunan Vol 31, No.2 Desember 2015.

kominfo.go.id

cikadu.desa.id

kompasiana.com

desamembangun.id

dpr.go.id 